\title{
Defining the Entrepreneurial Capital Construct
}

\author{
Paola Demartini \\ University of Rome TRE, Rome, Italy \\ Paola Paoloni \\ Niccolò Cusano University, Rome, Italy
}

\begin{abstract}
The purpose of this paper is to show preliminary results from an international research project on intellectual capital and value creation led by Lappeenranta University of Technology (Finland). In the case of this paper, results from Italy will be reported and specifically. The Italian analysis focuses on the entrepreneurial capital (EC) and it analyses how large Italian companies develop and enhance this intangible element. The main research question is: What is the current level of EC in Italian organizations and how does it affect value creation? To this end, the research addressed the different definitions of EC that literature offers. As a secondary step, this paper analysed the variables suggested by previous literature and proposed an original definition for the research project. The definition is that EC is a stock of competences and the personnels' attributes related to proactive, risky, and aggressive decision-making and behaviour. This research provides researchers and managers with unique insights into the evolutionary nature of the relationships between distinct IC variables and draws a picture on the state of art of corporate EC in the selected sample. This research highlights and improves companies' abilities to manage their EC. Furthermore, this research will set the agenda for improving the EC practices of Italian companies and will allow future comparison with firms from other countries that are participating in the same project identifying different pathways to success.
\end{abstract}

Keyword: entrepreneurial capital (EC), risk-taking, proactiveness and autonomy, aggressiveness

\section{Introduction}

The purpose of this paper is to show preliminary results from the Italian research unit of an international project on intellectual capital and value creation led by Lappeenranta University of Technology—LUT (Finland).

The two key academic discussions addressing knowledge in organizations are intellectual capital (IC) and knowledge management (KM) streams of research. In particular, IC literature focuses on intangible resources that contribute to value creation (Edvinsson \& Malone, 1997) that is "knowledge-based resources that contribute to the sustained competitive advantage of the firm" and "knowledge that can be converted into profits". However, very few earlier studies systematically combine IC and KM practices to examine the key knowledge-related factors impacting value creation in firms.

Yet, the main question of the overall project is how IC assets and their management practices interact to

Paola Demartini, full professor of Management and Accounting, Department of Business Studies, University of Rome TRE, Via Silvio D'Amico, Rome, Italy.

Paola Paoloni, associate professor, Department of UNISU, Niccolò Cusano University, Via Don Carlo Gnocchi, Italy.

Correspondence concerning this article should be addressed to Paola Demartini, Via Silvio D'Amico, 77-00145 Rome, Italy. E-mail: paola.demartini@uniroma3.it. 
create value. The common goal of the international research team is to examine the current state of IC stocks and KM practices, and how these interact in firms' value creation.

Academic partners involved in the project are the following:

- Lappeenranta University of Technology, Finland (the core team);

- University of Rome, Italy;

- Hong Kong Polytechnic University, China;

- Deusto Business School, University of Deusto, Spain;

- St. Petersburg University Graduate School of Management, Russia;

- Educons University, Serbia;

- Universidade Lusiada, Portugal;

- Academy of Economic Studies, Bucharest, Romania.

In most studies, IC has been seen to consist of three elements: human capital, structural capital, and relational capital (Bontis, 1998; Guthrie, 2001). The IC literature helps in identifying the kind of intangible resource stocks within the firms and in assessing them. However, are the above-mentioned three elements sufficient?

In this research design, it suggests that three additional elements could be included in IC visualizing and mapping: "renewal capital", in terms of innovative solutions, products, and services available for the firms, "trust capital" (i.e. the trust embedded in its internal and external relationship), and "entrepreneurial capital (EC)" (i.e. the competence and commitment related to entrepreneurial activities in the organization) (Kianto, 2007; Kianto, 2008; Kianto et al., 2013).

Within the overall project, the Italian research unit will focus on EC. In particular, how medium-sized and large Italian companies develop and enhance this intangible element will be analyzed. Consequently, the research questions of the investigation are the following: What is the current level of EC in Italian organizations and how does it affect value creation?

To this end, this investigation aims to highlight the importance of EC as a stand-alone component of the IC. As a secondary step, it will analyse the variables suggested by previous literature trying to understand this phenomenon and propose a definition that fits the research design. The emerging definition is that EC is a stock of competences and the personnels' attributes related to proactive, risky, innovativeness, and aggressive decision-making and behaviour.

This research agenda will provide academics and managers with unique insights into the state of the art of corporate EC in the selected sample.

Furthermore, this research will set the agenda for improving the EC practices of Italian companies and will allow future comparison with firms from other countries that are participating in the same project, identifying different pathways to success.

\section{Literature Review}

IC has been defined as "the total stock of capital or knowledge-based equity that the company possesses" (Dzinkowski, 2000). IC is either the end product of a knowledge transformation process or the stock of organizational knowledge itself. IC incorporates three main components that together form value: human capital, organizational (structural) capital, and customer (or relational) capital (Bontis, 1998; Guthrie, 2001).

Human capital refers to and includes know-how, education, work-related competencies, and psychometric assessments. McGregor, Tweed, and Pech (2004) defined human capital as the size and quality of broader labor 
markets, but also as the sum of individual competencies in organizations. Teece (2000) recognized that knowledge assets or products result from the experience and expertise of individuals. However, the "physical, social, and resource allocation structure" of organizations are important, if such experience and expertise are to be translated into competencies that help generate knowledge products (Teece, 2000; McGregor et al., 2004).

The term structural capital reflects these allocation structures and includes assets such as corporate culture, management processes, databases, organizational structure, patents, trademarks, and financial relations. Engstrom, P. Westnes, and S. Westnes (2003, p. 288) suggested that structural capital includes all non-human storehouses of knowledge in organizations.

Finally, relational or customer capital refers to, in part, an organization's customers, brands, customer loyalty, and distribution channels. Customer capital also refers to consumers as repositories of information and knowledge that is valuable to organizations (Bontis, 1998).

For the purpose of this research, it deems that EC (roughly intuitively defined as the competence and commitment related to entrepreneurial activities in the organization) should be taken into consideration as a stand -alone element of IC in the light of the following rationale:

- In an unsteady and unpredictable business environment like today, EC might be found as one of the most influent intangible to enhance corporate value;

- The construct of EC is characterized by several attributes which, in the traditional definition of IC refer both to human capital (i.e. entrepreneurial competence and behavior) and structural capital (i.e. entrepreneurial corporate culture and processes).

\section{Previous Studies in the Field of Entrepreneurship}

It must be highlighted that no previous research within the IC domain refers to EC, while many efforts have been made in the field of entrepreneurship studies especially to investigate the relationship between corporate Entrepreneurial Orientation (EO) (also called corporate entrepreneurship-CE) and firms' performance.

Lumpkin and Dess (1996) defined EO as the propensity of firms to be innovative and proactive to the market place opportunities and be willing to take risk. While the EO is identified as a process, the entrepreneurship is defined as the content.

To Schumpeter (1934), an entrepreneur is a person who carries out new combinations, which may take the form of new products, processes, markets, organizational forms, or sources of supply. Entrepreneurship is, then, the process of carrying out new combinations. In contrast, Gartner (1988) stated that entrepreneurship is the creation of organizations. Gartner was careful to specify that this was not offered as a definition but rather as an attempt to change a long held and tenacious viewpoint in the entrepreneurship field toward "what the entrepreneur does, not who the entrepreneur is" (1990, p. 26). Nevertheless, it is clear from the literature that a large number of researchers in entrepreneurship have employed this definition, including Gartner, Bird, and Starr (1991) and Learned (1992).

The analysis of EC can have effect on two levels: the individual or organizational level, and how the influence contributes to performance depends on these levels. EO by some scholars is associated only to small and medium-size enterprise (SMEs), because they are responsible for the majority of economic growth and new job creation (Birch, 1979). But recently, there has also been particular attention paid to CE as a means of growth and strategic renewal for existing larger firms (Guth \& Ginsberg, 1990). 
The organizational dimension may be viewed as encompassing the entire range of organizational activities that involve planning, decision making, strategic management, and many aspects of the organization's culture, i.e. shared value system and corporate vision. So many researchers have focused on delineating the dimension of EO in different ways.

Miller (1983) said that an entrepreneurial firm is the one that engages in product market innovation, undertakes somewhat risky ventures, and is first to come up with "proactive" innovations and beating competitors to the punch.

So, to understand EO constructs, it must be said that there are different definitions and that the scholars have used several variables to identify EO constructs. At the organisational level, Vesper (1984) defined CE as any one of or any possible combination of new strategic directions, initiative from below, and autonomous business creation.

In other circumstances, reference is made, describing it as a "process of transformation of organizations through strategic renewal" (Antoncic \& Hisrich, 2001; Guth \& Ginsberg, 1990), corporate venturing (creating business on existing or new fields, markets or industries using a core competency within a firm (Ellis \& Taylor, 1987; Narayanan, Yang, \& Zahra, 2009)), organizational innovation (Sharma \& Chrisman, 1999; Yiu \& Lau, 2008), as well as intrapreneuring (creating an entrepreneurial mindset or culture within a firm (Pinchot, 1985; Thornberry, 2001)).

At the individual level, EO has been associated to an individual who creates innovation of any kind within an established firm (Pinchot, 1985). A corporate entrepreneur is someone who engages in identifying and developing new opportunities relative to operations, methods, products or markets, sets the strategic vision for the organization or persuades the top management to adopt these opportunities, and motivates others to implement them (Ireland, Covin, \& Kuratko, 2009). In more general terms, corporate entrepreneurs are managers or employees who demonstrate key entrepreneurial attributes or behaviors within an established firm.

Each definition in the different levels (organizational or individual) has been associated with a number of characterizing variables that will be discussed in the following sections.

For each definition, all the researchers provided several variables to explain the meaning of EO/CE and its synonyms.

Each of the variables used was explained by attributing a shared definition. In the following sections, it'll report on the meanings of some of the variables used by the scholars:

- Innovativeness: developing new or improved products or services; involving radical and discontinuous change, improvement and redevelopment of existing products or processes, or the introduction of novel products or production methods based on new technology;

- Risk taking: measuring and taking risks for the sake of profits; taking bold actions such as venturing units into unknown new markets or committing a large portion of resources to ventures with uncertain outcomes; preference is for moderately high risks rather than extremely high risks;

- Networking: developing personal relationships in which others willingly defer to one's wishes; networks include all internal and external, as well as formal and informal relationships that share information, experiences and resources and/or provide social and emotional support; networks represent a source of power that facilitates the acquisition of physical and monetary resources and advice, information and reassurance;

- Integration: being involved in all aspects of the organization; requiring seeing things in a broader perspective, analyzing things in the abstract, and putting seemingly unrelated elements together in a meaningful 
way; involving the creating of a new order by selecting and fitting unrelated potential parts into a new pattern;

- Opportunism: recognising and exploiting opportunities to develop new products and processes, improve existing operations, and/or develop new marketing approaches; it may discover mundane opportunities that enhance efficiency or quality; evaluation of opportunities involves balancing inadequate commitment of resources and the potential for return;

- Non system-bound orientation: being unconstrained by rules, regulations and structures of existing organizational systems to be able to take advantage of opportunities; requiring manipulating or bypassing the system; such freedom must be justified from the perspective of organizational benefit;

- Change orientation: responding to environmental changes in a proactive or reactive manner; proactive approach involves taking the initiative to shape the environment to one's own advantage; reactive approach involves responding to changes rather than exploiting and initiating change;

- Flexibility in control: having the ability to adopt flexible planning systems and take varying degrees of control as appropriate to take advantage of emerging opportunities; facilitates changing strategic plans in response to highly complex and ever-changing environmental threats and opportunities;

- Informality: preferring simple systems and informal structures; characterized in terms of being autonomous, resistant towards conformity and having a low need for support; allowing for free crossing of organizational boundaries to promote a more open, cooperative atmosphere that is conducive to flexible decision-making processes, open communication and simplified work processes;

- Result orientation: focusing on results; making decisions and solving problems intuitively to foster commitment to action; it may become so immersed in work details that they are involved everywhere, ignoring corporate politics and individual egos, and violating bureaucratic procedures; similar to type a behavior in terms of intense competitiveness, time urgency, polyphasic behavior and preference of immediate action over planning.

Table 1

Literature Review: Definition of the Construct/Concept

\begin{tabular}{|c|c|c|c|c|}
\hline Authors & $\begin{array}{l}\text { Proposed } \\
\text { Construct/Concept }\end{array}$ & $\begin{array}{l}\text { Attributes/Variables Defining the } \\
\text { Construct/Concept }\end{array}$ & $\begin{array}{l}\text { Level: } \\
\text { Individual/ } \\
\text { Organisational }\end{array}$ & Journal \\
\hline Miller (1983) & $\begin{array}{l}\text { Entrepreneutrial } \\
\text { orientation }\end{array}$ & Innovation, proactiveness, risk- taking & organisational & Management Science \\
\hline $\begin{array}{l}\text { Covin and } \\
\text { Slevin (1989) } \\
\end{array}$ & Strategic posture & Innovation, proactiveness, risk-taking & organisational & $\begin{array}{l}\text { Strategic Management } \\
\text { Journal }\end{array}$ \\
\hline $\begin{array}{l}\text { Lumpkin and Dess } \\
\text { (1996) }\end{array}$ & $\begin{array}{l}\text { Entrepreneurial } \\
\text { orientation }\end{array}$ & $\begin{array}{l}\text { Propensity to act autonomously, } \\
\text { willingness to innovate, take risks, } \\
\text { tendency to be aggressive toward, } \\
\text { competitors, tendency to be proactive } \\
\text { toward marketplace opportunities }\end{array}$ & $\begin{array}{l}\text { individual/ } \\
\text { organisational }\end{array}$ & $\begin{array}{l}\text { Academy of } \\
\text { Management Review }\end{array}$ \\
\hline Zahra (1996) & $\begin{array}{l}\text { Corporate } \\
\text { entrepreneurship }\end{array}$ & Innovation, venturing, strategic renewal & organisational & $\begin{array}{l}\text { Academy of } \\
\text { Management Journal }\end{array}$ \\
\hline $\begin{array}{l}\text { Dess, Lumpkin, } \\
\text { and Covin (1997) }\end{array}$ & $\begin{array}{l}\text { Entrepreneurial } \\
\text { strategy making }\end{array}$ & $\begin{array}{l}\text { Top management "intentionality", } \\
\text { organisational actor "autonomy" }\end{array}$ & organisational & $\begin{array}{l}\text { Strategic Management } \\
\text { Journal }\end{array}$ \\
\hline $\begin{array}{l}\text { Barrett, Balloun, } \\
\text { and Weinstein } \\
(2000)\end{array}$ & $\begin{array}{l}\text { Corporate } \\
\text { entrepreneurship }\end{array}$ & Innovation, proactiveness, risk-taking & organisational & $\begin{array}{l}\text { Journal of Marketing } \\
\text { Theory and practice }\end{array}$ \\
\hline $\begin{array}{l}\text { Goosen, De } \\
\text { Coning, and Smit } \\
\text { (2002) }\end{array}$ & $\begin{array}{l}\text { Corporate } \\
\text { entrepreneurship }\end{array}$ & $\begin{array}{l}\text { Innovation, proactiveness, management's } \\
\text { internal influence and relations }\end{array}$ & organisational & $\begin{array}{l}\text { South African Journal of } \\
\text { Business Management }\end{array}$ \\
\hline
\end{tabular}


Table 1 to be continued

\begin{tabular}{|l|l|l|l|l|}
\hline Authors & $\begin{array}{l}\text { Proposed } \\
\text { Construct/Concept }\end{array}$ & $\begin{array}{l}\text { Attributes/Variables Defining the } \\
\text { Construct/Concept }\end{array}$ & $\begin{array}{l}\text { Level: } \\
\text { Individual/ } \\
\text { Organisational }\end{array}$ & Journal \\
\hline $\begin{array}{l}\text { Antoncic and } \\
\text { Hisrich } \\
(2003)\end{array}$ & $\begin{array}{l}\text { Corporate } \\
\text { entrepreneurship }\end{array}$ & $\begin{array}{l}\text { New venture formation, product/service } \\
\text { innovation, process innovation }\end{array}$ & organisational & $\begin{array}{l}\text { Journal of } \\
\text { Developmental } \\
\text { Entrepreneurship }\end{array}$ \\
\hline $\begin{array}{l}\text { Yiu and Lau } \\
(2008)\end{array}$ & $\begin{array}{l}\text { Corporate } \\
\text { entrepreneurship }\end{array}$ & Innovation, venturing, strategic renewal & organisational & $\begin{array}{l}\text { Entrepreneurship Theory } \\
\text { and Practice }\end{array}$ \\
\hline $\begin{array}{l}\text { Heavey, Simsek, } \\
\text { Roche, and Kelly } \\
(2009)\end{array}$ & $\begin{array}{l}\text { Corporate } \\
\text { entrepreneurship }\end{array}$ & Innovation, venturing, renewal & organisational & $\begin{array}{l}\text { Journal of Management } \\
\text { Studies }\end{array}$ \\
\hline $\begin{array}{l}\text { Ireland et al. } \\
(2009)\end{array}$ & $\begin{array}{l}\text { Corporate } \\
\text { entrepreneurship } \\
\text { strategy }\end{array}$ & $\begin{array}{l}\text { Top-management's entrepreneurial, strategic } \\
\text { vision, pro-entrepreneurship organisational } \\
\text { architecture, entrepreneurial processes and } \\
\text { behaviour }\end{array}$ & organisational & $\begin{array}{l}\text { Entrepreneurship Theory } \\
\text { and Practice }\end{array}$ \\
\hline
\end{tabular}

As can be seen in the previous table (Table 1), key words to define $\mathrm{EO} / \mathrm{CE}$ are the following: risk taking, proactiveness, and innovation.

Despite many names and many variables studied, it is yet unclear that how these dimensions and business performance are linked. It is evident that all or at least a combination of some, exhibit some relationship with business performance, generally a positive link.

Lumpkin and Dess (1996) reasoned that the different variables of EC might lead to favorable outcomes on one performance dimension but unfavorable outcomes on another and this may also depend on different firm conditions (size, age, and firm context).

\section{Research Design: From EO to EC}

For the purpose of the current research, drawing from the above-mentioned literature, EC is comprehensively defined as a stock of competences and the personnels' attributes related to proactive, risky, innovative, and aggressive decision-making and behavior:

- Proactiveness means taking initiative by anticipating and pursuing new opportunities, and participating in emerging markets also has become associated with entrepreneurship;

- Risky reflects an acceptance of uncertainty and risk inherent in original activity and is typically characterized by resource commitment to uncertain outcomes and activities;

- Aggressive decision-making is the intensity with which a firm chooses to compete and efforts to surpass competitors reflecting a bias toward out doing rivals. Also it includes the authority and independence given to an individual or team within the firm to develop business concepts and vision and carry them through to completion (Hughes \& Morgan, 2007);

- Innovativeness reflects the propensity of the firm to engage in a new idea and new processes and also new creative solutions and opportunities (Wiklund \& Shepherd, 2003).

To further address how the different dimensions are related to performance and value creations, this paper here overviews several hypotheses. In fact, to draw the research design, it is necessary to examine how each individual variable of EC might influence business performance and value creation.

This paper will explore each above-mentioned dimension and investigate why a specific variable might have a positive influence on business performance and value creation.

HP 1: Proactiveness is positive linking with performance and value creation. 
Proactiveness represents a forward-looking perspective where firms actively seek to anticipate opportunities to develop and introduce new or improved products, instigate changes to current strategies and tactics, and detect future trends in the market (Lumpkin \& Dess, 1996; Slater \& Narver, 1995).

Proactive firms, through proprietary learning and experience effects gained over time, tend to be more attuned to changes and trends in the marketplace, which yields opportunities to the firm to meet expressed and latent needs ahead of competitors (Hamel \& Prahalad, 1991).

Proactiveness in firms is characterized by intentional change, that is, by force, acting on information to make change, not merely anticipating it (Bateman \& Crant, 1993). This alleviates the risk of complacency by ensuring that firms are better placed to serve markets in the short term and shape them in the longer term. The emphasis on anticipating and acting on future needs orients the firm to seize initiative and act opportunistically in the marketplace, thereby shaping demand (Miller \& Friesen, 1978).

HP 2: Risk-taking is positive related with performance and value creation.

Risk-taking represents a willingness to commit resources to implement projects, activities, and solutions that contain inherently a high level of uncertainty regarding the likely outcomes (Lumpkin \& Dess, 1996). When deciding to take risks, firms must tolerate one of two possible scenarios- the first being the risk of failing and second, the risk of missing out on an opportunity (Dickson \& Giglierano, 1986). The former is caused by fear, whereas the latter is caused by inaction. A tolerance of risk-taking orients the firm towards action and induces it to embrace uncertainty.

Timely risk-taking has been associated with strategic decision-speed and both have subsequently been linked to improved business performance (Eisenhardt, 1989).

Risk-oriented firms combine opportunity-seeking behavior with constructive risk-taking to generate a bias for exploration and exploitation (Baird \& Thomas, 1990; Lumpkin \& Dess, 1996).

Risk-taking managements usually seize opportunities and make commitments of resources before fully understanding what action needs to be taken (Covin \& Slevin, 1991). Such an approach seeks to take advantage of evolving situations by capitalizing on the fact that markets rarely stabilize for any length of time. Risk aversion renders firms passive to developing new market opportunities, which is likely to deteriorate performance in an age of rapid change (Miller \& Friesen, 1978).

HP 3: Aggressive decision-making is positive related with performance and value creation.

Firms that are highly aggressive see competitors as enemies that must be conquered.

Aggressiveness can be implemented through the mobilization of resources to launch direct attacks on competitors with the aim of overwhelming their market efforts, steadily erode their competitive strengths, or establish advantage through continuous offensive tactics (Davidson, 1987).

Aggressiveness can improve performance because the emphasis on out-doing and out-maneuvering competitors strengthens the firm's competitiveness at the expense of rivals (Lumpkin \& Dess, 1996). Examples of the manifestation of such an aggressive competitive strategy include aggressive price competition, market entry with a new or superior offering, fast-following a rival into a market, continuously exploiting information, and using unconventional surprise tactics.

Such an emphasis on acquiring market share and customers by aggressively targeting rivals' weaknesses should improve performance, because it undermines competitors' ability to compete and restricts the ability of competitors to anticipate and respond to what the aggressive firm will do next. Since the aggressive firm does not sit still and constantly implements incremental and adaptive change to undermine competitors, it is 
hypothesized that autonomy conveys the freedom to employees to encourage them to be self-directed, to exercise creativity, pursue opportunities, and champion new ideas which are essential for effective entrepreneurial activity to occur (Lumpkin \& Dess, 1996).

Autonomy is, therefore, an important driver of flexibility, which is an essential attribute, if a firm is to be able to respond promptly to environmental change and market signals by quickly reconfiguring its actions and activities (Grewal \& Tansuhaj, 2001). Flexibility is created, when people within the firm are given freedom to apply their human capital in ways that help the firm change adaptively and be responsive to the needs of its markets and actions of its rivals. A lack of autonomy would likely result in passivity when change is needed to initiate an effective response to opportunities and threats to performance. The presence of autonomy, in contrast, should encourage a greater flexibility in the firm to facilitate active and reactive response to change. Although some framework of coordination is likely to be needed, on balance, it can be expected that autonomy will be beneficial to improving business performance.

HP 4: Innovativeness is positive related with performance and value creation.

Innovativeness represents a bias toward embracing and supporting creativity, experimentation, technological leadership, and R\&D in the development of products, services, and processes to generate novel solutions to customer needs and problems (Hughes \& Morgan, 2007). It is said to be present when firms pursue active implementation of new ideas, products or processes, not merely their generation (Hurley \& Hult, 1998).

Calantone, Çavuşgil, and Zhao (2002) established that firm innovativeness has a positive impact on performance and contributes to competitive advantage by facilitating creative thinking within a firm's learning activities. Innovativeness also improves the application of market intelligence acquired through market orientation activities, which can benefit performance (Han, Kim, \& Srivastava, 1998; Hurley \& Hult, 1998). Also, a study by Hult, Hurley, and Knight (2004) uncovered that innovativeness benefits business performance regardless of market turbulence. Innovativeness changes how a firm applies market information (Slater \& Narver, 1995) and together informs the generation of intelligent solutions.

\section{Survey}

While the Italian research unit focuses on the EC, the overall research design aims to understand links between IC managing and value creation.

In the next paragraphs, the following steps will be addressed:

(1) Operationalising variables;

(2) Survey data collection;

(3) Target respondent;

(4) Public data collection.

\section{Operationalising Variables}

Operationalising variables in social science involves defining a concept so that it can be measured. All variables defining EC were addressed and discussed in meetings of the international working group.

As far as EC is concern, the followings are the operationalised variables and the related statement included into the questionnaire (Table 2).

It must be noted that in the social sciences, much of what people study is measured on what would be classified as an ordinal level. In the questionnaire, authors then assign a value of "1" if interviewees completely 
disagree with the statement, up to a " 5 " if they completely agree with the statement.

The finalized research instrument (survey questionnaire) was distributed in the beginning of September 2013 by the LUT research team.

The questionnaire was in English. Each partner should take care in translating the questionnaire to their own language. Utilization of professional interpreter was the first step. Additionally, the substance and flow of the questions were finally checked by the Italian research team to ensure that respondents could answer the research questions. The core message of each item should remain the same to ensure standardization and applicability of the measures across countries.

The survey was conducted in exactly the same format in all cases. This means using all of the items in the survey, and in the same order, and with the same scales. The data were collected using survey questionnaires by the end of the year 2013.

Publicly available data were collected right after the primary data collection ended.

Table 2

Entrepreneurial Capital: Operationalised Variables and Related Statements

\begin{tabular}{|l|l|l|}
\hline \multirow{4}{*}{ ENTCAP } & Concept & Entrepreneurial capital \\
\cline { 2 - 3 } & \multirow{3}{*}{ Variables } & Risk-taking \\
\cline { 3 - 3 } & & Proactiveness \\
\cline { 3 - 3 } & & Aggressive decision-making \\
\cline { 2 - 3 } & & Innovativeness \\
\hline
\end{tabular}

To what extent do the following statements on the entrepreneurial orientation apply to your company? $(1=$ completely disagree, $5=$ completely agree)

\begin{tabular}{|l|l|}
\hline & \\
\hline ENTCAP1 & Risk-taking is regarded as a positive personal quality in our company. \\
\hline ENTCAP2 & Our employees take deliberate risks related to new ideas. \\
\hline ENTCAP3 & Our employees are excellent at identifying new business opportunities. \\
\hline ENTCAP4 & Our employees show initiative. \\
\hline ENTCAP5 & The operations of our company are defined by independence and freedom in performing duties. \\
\hline ENTCAP6 & Our employees have the courage to make bold and difficult decisions. \\
\hline ENTCAP7 & The operations of our company can be described as creative and inventive. \\
\hline
\end{tabular}

\section{Survey Data Collection and Targeted Population of Firms}

In particular, the target population is made up of Italian limited liabilities companies with 100 or more employees. The companies involved were selected among 2,000 companies chosen by a random sampling procedure from the database AIDA, but according to the mix of a stratified sample representative of all population of the database (that is, companies were randomly chosen within a fixed percentage according to geographical area, sector of activity and size).

The main goal was to get a multi-industry sample with a representative variety of firms within Italy.

Up to April 2014, 100 companies have answered the questionnaire so far and this number is expected to increase during the next month. Additional economic and financial ratios have been obtained from AIDA database, which contains economic and financial information for Italian firms. Descriptive analysis techniques will then be applied and differences according to industry and size will be explored.

AIDA data base covers one million companies in Italy and it contains comprehensive information on Italian companies, including: detailed accounts following the scheme of the fourth directive CEE, indicators and trade description of Italian companies, ownership and management, consolidated accounts, and accounts in IFRS. 


\section{Targeted Respondent/Informant}

The survey should be answered by one key informant from each firm, preferably CEO, because the CEO will have the best knowledge about the themes covered in the survey.

If the CEO cannot be realistically reached, the other high-level directors/managers in the following fields are feasible respondents (in the order of preference):

- Chief operating officer;

- HR/KM director;

- Development director.

The data have been collected from October 2013 and March 2014. A hybrid approach to gather data has been followed, first by internet survey: The research team used an internet-administered survey questionnaire (Google questionnaire), and sent each respondent a link to the questionnaire. This also allowed for follow-ups and reminders. Then to increase the number of filled in questionnaires, the respondents were called via phone and each question was asked and filled by the research team. Finally, it is via face to face interviews.

In order to make respondents comfortable and willing to fill out the questionnaire information about why the survey is conducted and how the data will be utilized, instructions for the answering were given. Furthermore, it emphasizes the confidentiality in analyzing the data and authors promise them to receive a managerial report concerning the country's results.

\section{Public Data Collection}

Then the following corporate performance measures were collected trough AIDA database:

- Return on assets (ROA) last three years;

- Return on equity (ROE) last three years;

- Growth in revenue last three years;

- Growth in turnover/sales last three years.

While control variables are the following:

- Sales/Turnover $(2010,2011,2012)$;

- The number of personnel $(2010,2011,2012) ;$

- Year of foundation/establishment ;

- Market to book value or price to book value (P/B), if available;

- Industry information (NACE coding highly preferable, or other official industry coding).

\section{First Results}

More than $50 \%$ of all respondents (value $=>3$ ) agree that in their companies there is a satisfactory level of EC as defined by the above-mentioned variables (Table 3 ).

Table 3

First Results

\begin{tabular}{llrrrrr}
\hline VAR & KEY WORD & 1 & 2 & 3 & 4 & 5 \\
\hline ENTCAP1 & risk-taking & 2 & 20 & 19 & 40 & 19 \\
ENTCAP2 & new ideas & 7 & 26 & 30 & 30 & 7 \\
ENTCAP3 & new business & 8 & 30 & 32 & 25 & 5 \\
ENTCAP4 & initiative & 4 & 20 & 31 & 35 & 10 \\
ENTCAP5 & independence & 5 & 19 & 32 & 35 & 9 \\
ENTCAP6 & difficult decision & 10 & 22 & 38 & 24 & 6 \\
\hline
\end{tabular}

Notes. Frequency of answers (\%); Total $=100$ questionnaires. 


\section{Conclusions}

As stated in the introduction, this is a first conceptual paper on "IC and value creation", aiming to:

- enlightening the overall framework of the international project and the specific role of the Italian unit;

- explaining why EC should be considered — for the purpose of our investigation, as a stand-alone element of IC;

- illustrating the research methodology of the Italian research unit;

- defining and operationalise the concept of EC.

In the first step, the Italian research team will address a deep analysis of data gathered in order to describe what the current level of EC in Italian medium-sized and large companies is. Clusters of firms by dimension, activity sector, and geographical location will be investigated.

Future research agenda considers comparison with results emerging in other countries in order to address environmental variables effects on EC, IC, and corporate performance.

Finally, next year causality relation between EC and value performance will be tested.

\section{References}

Antoncic, B., \& Hisrich, R. D. (2001). Intrapreneurship construct: Refinement and cross-cultural validation. Journal of Business Venturing, 16(5), 495-527.

Antoncic, B., \& Hisrich, R. D. (2003). Privatization, corporate entrepreneurship and performance: Testing a normative model. Journal of Developmental Entrepreneurship, 8(3), 197-218.

Baird, I. S., \& Thomas, W. (1990). What is risk anyway? Using and measuring risk in strategic management. In R. A. Bettis, \& H. Thomas (Eds.), Risk, strategy, and management (pp. 21-52). Greenwich: JAI Press.

Barrett, H., Balloun, J. L., \& Weinstein, A. (2000). Marketing mix factors as moderators of the corporate entrepreneurship - Business performance relationship-A multistage, multivariate analysis. Journal of Marketing Theory and Practice, 8(2), 50-63.

Bateman, T. S., \& Crant, J. M. (1993). The proactive component of organizational behavior: A measure and correlates. Journal of Organizational Behavior, 14(2), 103-118.

Birch, D. (1979). The job generation process. Mit program on neighborhood and regional change. Cambridge: MIT press.

Bontis, N. (1998). Intellectual capital: An exploratory study that develops measures and models. Management Decision, 36(2), 63-75.

Calantone, R. J., Çavuşgil, S. T., \& Zhao, Y. (2002). Learning orientation, firm innovation capability, and business performance. Industrial Marketing Management, 31, 515-524.

Covin, J. G., \& Slevin, D. P. (1989). Strategic management of small firms in hostile and benign environments. Strategic Management Journal, 10(1), 75-87.

Davidson, H. (1987). Offensive marketing: How to make your competitors followers. London: Penguin.

Dess, G. G., Lumpkin, G. T., \& Covin, J. G. (1997). Entrepreneurial strategy making and firm performance: Test of contingency and configurational models. Strategic Management Journal, 18(9), 677-695.

Dickson, P. R., \& Giglierano, J. J. (1986). Missing the boat and sinking the boat: A conceptual model of entrepreneurial risk. Journal of Marketing, 50, 58-70.

Dzinkowski, R. (2000). The measurement and management of intellectual capital: An introduction. Management Accounting, $78(2), 32-36$.

Edvinsson, L., \& Malone, M. S. (1997). Intellectual capital. London: Piatkus.

Eisenhardt, K. M. (1989). Making fast strategic decisions in high-velocity environments. Academy of Management Journal, 27, 299-343.

Ellis, R. J., \& Taylor, N. T. (1987). Specifying entrepreneurship. In N. C. Chruchill, J. A. Hornaday, B. A. Kirchhoff, O. J. Krasner, \& K. H. Vesper (Eds.), Frontiers of entrepreneurship research (pp. 527-541). Wellesley: Babson College.

Engstrom, T. E. J., Westnes, P., \& Westnes, S. (2003). Evaluating intellectual capital in the hotel industry. Journal of Intellectual Capital, 4(3), 287-303. 
Gartner, W. B., Bird, B. J., \& Starr, J. A. (1991). Acting as if: Differentiating entrepreneurship from organizational behavior. Entrepreneurship Theory and Practice, 16(3), 13-31.

Gartner. W. B. (1988). "Who is an entrepreneur?" is the wrong question. American Journal of .Small Business, 12(4), 11-32.

Gartner. W. B. (1990). What are we talking about when we talk about entrepreneurship? Journal of Business Venturing, 5, 15-28.

Goosen, C. J., De Coning, T. J., \& Smit, E. V. D. M. (2002). Corporate entrepreneurship and financial performance: The role of management. South African Journal of Business Management, 33(4), 21-27.

Grewal, R., \& Tansuhaj, P. (2001). Building organizational capabilities for managing economic crisis: The role of market orientation and strategic flexibility. Journal of Marketing, 65, 67-80.

Guth, W. D., \& Ginsberg, A. (1990). Corporate entrepreneurship. Strategic Management Journal, 11(5), 5-15.

Guthrie J. (2001). The management, measurement and the reporting of intellectual capital. Journal of Intellectual Capital, 2(1), $27-41$.

Hamel, G., \& Prahalad, C. K. (1991). Corporate imagination and expeditionary marketing. Harvard Business Review, 69, 81-92.

Han, J., Kim, N., \& Srivastava, R. (1998). Market orientation and organizational performance: Is innovation a missing link? Journal of Marketing, 62, 30-45.

Heavey, C., Simsek, Z., Roche, F., \& Kelly, A. (2009). Decision comprehensiveness and corporate entrepreneurship: The moderating role of managerial uncertainty preferences and environmental dynamism. Journal of Management Studies, 46(8), 1289-1314.

Hughes, M., \& Morgan, R. E. (2007). Deconstructing the relationship between entrepreneurial orientation and business performance at the embryonic stage of firm growth. Industrial Market Management, 36, 651-661.

Hult, G. T. M., Hurley, R. F., \& Knight, G. A. (2004). Innovativeness: Its antecedents and impact on business performance. Industrial Marketing Management, 33, 429-438.

Hurley, R. F., \& Hult, G. T. M. (1998). Innovation, market orientation, and organizational learning: An integration and empirical examination. Journal of Marketing, 62, 42-54.

Ireland, R. D., Covin, J. G., \& Kuratko, D. F. (2009). Conceptualizing corporate entrepreneurship strategy. Entrepreneurship Theory and Practice, 33(1), 19-46.

Kianto, A. (2007). What do we really mean by dynamic intellectual capital? International Journal of Learning and Intellectual Capital, 4(4), 342-356.

Kianto, A. (2008). Development and validation of a survey instrument for measuring organizational renewal capability. International Journal of Technology Management, 42(1), 69-88.

Kianto, A., Ritala, P., Inkinen, H., \& Vanhala, M. (2013). The interaction of intellectual capital stocks and knowledge management practices in organizational value creation. Proceedings from 8th International Forum on Knowledge Asset Dynamics-IFKAD 2013, Zagreb.

Learned, K. E. (1992). What happened before the organization? A model of organizational formation. Entrepreneurship Theory and Practice, 17(1), 39-48.

Lumpkin, G. T., \& Dess, G. (1996). Clarifying the entrepreneurial orientation construct and linking it to performance. Academy of Management Review, 21, 135-172.

McGregor, J., Tweed, D., \& Pech, R. (2004). Human capital in the new economy: Devil's bargain? Journal of Intellectual Capital, 5(1), 153-164.

Miller, D. (1983). The correlates of entrepreneurship in three types of firms. Management Science, 29(7), 770-791.

Miller, D., \& Friesen, P. H. (1978). Archetypes of strategy formulation. Management Science, 24, 921-933.

Narayanan, V. K., Yang, Y., \& Zahra, S. (2009). Corporate venturing and value creation: A review and synthesis. Research Policy, $38(1), 58-76$.

Pinchot, G. (1985). Intrapreneuring. New York: Harper \& Row.

Schumpeter, J. A. (1934). The theory of economic development. Cambridge: Harvard University Press.

Sharma, P., \& Chrisman, S. J. J. (1999). Toward a reconciliation of the definitional issues in the field of corporate entrepreneurship. In A. Cuervo, D. Ribeiro, \& S. Roig (Eds.), Entrepreneurship: Concepts, theory and perspective (pp. 83-103). Berlin: Springer-Verlag.

Slater, S. F., \& Narver, J. C. (1995,). Market orientation and the learning organization. Journal of Marketing, 59, 63-74.

Stovel, M., \& Bontis, N. (2002). Voluntary turnover: Knowledge management-Friend or foe? Journal of Intellectual Capital, $3(3), 303-322$

Teece, D. J. (2000). Managing intellectual capital. Oxford: Oxford University Press. 
Thornberry, N. (2001). Corporate entrepreneurship: Antidote or oxymoron. European Management Journal, 19(5), $526-533$.

Vesper, K. H. (1984). Three faces of corporate entrepreneurship: A pilot study (Frontiers of Entrepreneurship Research, Babson College, Boston, MA, pp. 294-320).

Wiklund, J., \& Shepherd, D. (2003). Knowledge-based resources, entrepreneurial orientation, and the performance of small and medium-sized businesses. Strategic Management Journal, 24, 1307-1314.

Yiu, D. W., \& Lau, C. M. (2008). Corporate entrepreneurship as resource capital configuration in emerging market firm. Entrepreneurship Theory and Practice, 32(1), 37-57.

Zahra, S. A. (1996). Governance, ownership and corporate entrepreneurship: The moderating impact of industry technological opportunities. Academy of Management Journal, 39(6), 1713-1735. 